\title{
Ontogenetic change of foraging behaviour during copepodite development of Acartia clausi
}

\author{
Kazutaka Takahashi $^{1, *}$, Peter Tiselius ${ }^{2}$ \\ ${ }^{1}$ Tohoku National Fisheries Research Institute, Fisheries Research Agency, 3-27-5, Shinhama-cho, Shiogama, \\ Miyagi 985-0001, Japan \\ ${ }^{2}$ Department of Marine Ecology, Göteborg University, Kristineberg Marine Research Station, 45034 Fiskebäckskil, Sweden
}

\begin{abstract}
Swimming behaviour of copepodite stage CI to adults of the planktonic copepod Acartia clausi were observed at different food levels $\left(0,60,500\right.$ and $\left.2000 \mathrm{cells} \mathrm{ml}^{-1}\right)$ of the diatom Thalassiosira weissflogii. Concurrent measures of clearance in bottle incubations were performed for CI and adult females. All indivuduals exhibited typical jump-sink behaviour. At low food concentrations early copepodites filtered $36 \%$ of the time, and later stages $18 \%$, yet the increased suspension-feeding effort did not enhance their clearance rate. Older stages and adults did not show feeding-bouts at low food concentrations, which is interpreted as a switch to the ambush-feeding mode, whereby the copepods are assumed to be searching for potentially abundant larger and motile prey, for instance, ciliates. When offered no food, frequent and long jumps were observed in all stages except for CI. Search volumes during ambush feeding were estimated, and the slow sinking of early stages resulted in a small search volume as compared to that in later stages. Early copepodite stages depended to a higher degree on suspension feeding, regardless of food concentration, due to their undeveloped food searching ability. High food availability is therefore crucial for the growth and survival of early copepodite stages of A. clausi. The heavier body of later stages enhanced foraging efficiency both during suspension feeding (by gravity tethering) and in ambush feeding (by faster sinking).
\end{abstract}

KEY WORDS: Swimming behaviour - Suspension feeding $\cdot$ Ambush feeding $\cdot$ Switching behaviour · Lower feeding threshold $\cdot$ Life history $\cdot$ Calanoid

Resale or republication not permitted without written consent of the publisher

\section{INTRODUCTION}

Pelagic copepods pass through 6 naupliar and 5 copepodite stages prior to reaching the adult stage. Nauplii generally have an oval-shaped body, and they use the second antennae and mandibles for feeding and swimming (Björnberg 1986, Paffenhöfer \& Lewis 1989, Mauchline 1998). Copepodites resemble adults with complete sets of mouth parts, but exhibit progressive development of the appendages and segmentation with increase of body size. Juvenile copepods often exceed adults in terms of numbers and biomass, and play an important role in the food web both as grazers and as prey. This role changes during development, and the size and type of prey captured as well as vulnerability to predation may also change (e.g.
Buskey 1994, Swalding \& Marcus 1994). Our understanding of the ecology of juvenile copepods is still limited compared to what we know of adults.

Knowledge of the swimming behaviour of copepods is essential to explain prey selectivity and susceptibility to predation as well as copepod migration and distribution patterns (e.g. Jonsson \& Tiselius 1990, Osgood \& Frost 1994, Kiørboe et al. 1996, Tiselius et al. 1997, Titelman \& Fiksen 2004). Much attention has recently been paid to the behaviour of nauplii and their importance as prey organisms (e.g. Titelman 2001, Titelman \& Kiørboe 2003a,b, Jiang \& Paffenhöfer 2004). In contrast, development of behaviour throughout the copepodite stages (CI copepodite to adults) has been less well examined, probably because they visually resemble adults, varying only in size (Allan et al. 
1977). Previous observations have shown that the swimming pattern changes little throughout copepodite development (e.g. Van Duren \& Videler 1995, Paffenhöfer et al. 1996) or that, in some species, early copepodite stages have different swimming behaviours (Paffenhöfer \& Lewis 1989, Paffenhöfer et al. 1996).

The swimming behaviour of copepods is constrained by the physical properties of water. Strickler (1982) found that copepods during suspension feeding are 'tethered' by gravity, allowing them to create a feeding current. In small zooplankton $(<0.6 \mathrm{~mm})$, however, hydrodynamic theory predicts that drag replaces gravity as a tether force (Emlet \& Strathmann 1985). Tiselius \& Jonsson (1990) suggested that the energetic cost to remain suspended should be small for copepods $<0.6 \mathrm{~mm}$ and that different sizes would affect efficiency in the ambush-feeding mode, since it involves sinking during prey search (e.g. Jonsson \& Tiselius 1990, Kiørboe et al. 1996, Svensen \& Kiørboe 2000). The size at which marked changes occur in these models are within the range of copepodites of most coastal calanoid copepods. The models also predict an ontogenetic modification of the optimal foraging strategy, but this prediction has not been investigated. Feeding mode, starvation tolerance and susceptibility to predation are all key factors in the foraging strategy.

In this study we investigated the ontogenetic change of foraging behaviour in copepodites and adults of Acartia clausi. This species and its congeners are ubiquitous in coastal temperate water, and the adult female is known to show a switching behaviour between suspension- and ambush-feeding modes depending on food availability (Kiørboe et al. 1996, Gismervik \& Andersen 1997). Our study consists of behavioural observations and feeding experiments and demonstrates that the relative time allocation to each feeding mode varies during copepodite development. Possible causes for and implications of ontogenetic shifts in foraging strategies are discussed.

\section{MATERIALS AND METHODS}

Collection and maintenance. Experiments were conducted from July to October in 2003 and 2004. Acartia clausi were collected from the Gullmar fjord close to the Kristineberg Marine Research Station, on the morning of the day of the experiments using a plankton net (90 or $200 \mu \mathrm{m}$ mesh). In the laboratory, copepods were sorted and placed in filtered seawater for 1 to $2 \mathrm{~h}$ and then acclimated to the experimental conditions for at least $1 \mathrm{~h}$ before the filming or the feeding experiments. All observations and experiments were conducted in a dark room at $18^{\circ} \mathrm{C}$.
Observation of behaviour. The swimming behaviour was investigated by filming individual copepods in small Plexiglas aquaria $(50 \times 50 \times 200 \mathrm{~mm}$ high $)$. Four different treatments were used: filtered seawater and suspensions of 60,500 and 2000 cells ml-1 of the diatom Thalassiosira weissflogii (12.6 $\mu \mathrm{m}$ equivalent spherical diameter, ESD). The T. weissflogii strain was provided by the Marine Algal Culture Centre at Göteborg University (GUMACC) and grown at $18^{\circ} \mathrm{C}$ in batch cultures using B1 medium + vitamins under a $12 \mathrm{~h}$ light: $12 \mathrm{~h}$ dark illumination regime provided by cool white fluorescent lamps. T. weissflogii was selected since it is captured with $100 \%$ efficiency by all copepodite stages of Acartia clausi (Nival \& Nival 1976, Dexter 1986). Only 1 copepod in each aquaria was observed, and each individual received a fresh suspension of algae. Filming was performed with a CCD-camera (OSCAR-458) fitted with a macro-lens (Vivitar $100 \mathrm{~mm}$ ). The camera was connected via a time-date generator (Panasonic, WJ-810) to a VCR (Panasonic, NV-FS200) and a monitor. All observations were made in a dark room, and illumination consisted of an array of $880 \mathrm{~nm}$ infrared (IR) diodes. After observation, copepods were fixed with formaldehyde for subsequent determination of stage and body (prosome) length with a stereomicroscope and micrometer. The filming was conducted between 12:00 and 16:00 h to avoid effects of endogenous rhythms.

Swimming behaviour was recorded from the video tapes by frame-by-frame analysis with a transparency sheet mounted on the monitor. Behaviours were divided into sequences of: (1) sinking (no appendage movements), (2) feeding-bouts (slow swimming with movements of feeding appendages) and (3) jumps (swift displacements lasting 0.04 to $0.12 \mathrm{~s}$ ). Two types of jumps were distinguished: long jumps ( $>0.5$ body length) and feeding-bout-associated short jumps $(<0.5$ body length). The short jumps occurred at the end of a feeding-bout and resulted in the reorientation of the body from a vertical to a horizontal position (Saiz \& Alcaraz 1992, Tiselius 1992, Saiz 1994, Tiselius et al. 1997). Frequencies of jumps and feeding-bouts were estimated for the sequences analysed. Distance and velocities of sinking and jumping events were calculated by tracking successive copepod positions (the tip of the head; $0.02 \mathrm{~s}$ resolution). Finally, time budgets were calculated for the 3 behaviours of sinking, swimming and jumping. Only sequences in which the copepod trajectory could be determined with good focus were used for the analysis. Periods when the copepods were close to the surface, bottom, or walls of the aquarium were excluded from the analysis. For each copepodite stage and each food treatment, 3 to 7 individuals were observed for at least $30 \mathrm{~s}$ ind. ${ }^{-1}$, resulting in 118 copepods analysed for $4945 \mathrm{~s}$ in total. 
Feeding experiments. Feeding experiments were carried out in order to compare the time budgets to actual food intake. Clearance was estimated by incubating copepodite $\mathrm{CI}$ and adult females in glass bottles with a suspension of algae. A total of 10 adult females or $40 \mathrm{CI}$ copepodites were placed into each of 3 to 4 screw-cap glass bottles (400 ml for adult females, $100 \mathrm{ml}$ for CI) containing a suspension of Thalassiosira weissflogii at 60, 500 , or 2000 cells $\mathrm{ml}^{-1}$. Three bottles without copepods served as controls. The bottles were incubated standing in a dark room for $4 \mathrm{~h}$ (12:00 to 16:00 h) to make the conditions similar to the filming conditions. The number of cells was determined with an Elzone 5380 electronic particle counter with threshold settings to avoid electronic noise (active window: 9.948 to $18.47 \mu \mathrm{m}$ ESD, peak at 12.58). Microscopic inspection of cell cultures, as well as samples drawn from the end of experiments, showed no particles other than algal cells. The clearance and ingestion rates were calculated using the equations of Frost (1972). Since T. weissflogii is retained with $100 \%$ efficiency, clearance equals the volume of water filtered by Acartia clausi.

Estimation of search volume in ambush feeding. When Acartia spp. sink, they display the ambush-feeding mode, i.e. searching for larger and/or moving prey (e.g. ciliates, Jonsson \& Tiselius 1990). Copepods detect prey by means of mechanoreceptors on the first antennae (Paffenhöfer \& Stearns 1988, Jonsson \& Tiselius 1990, Kiørboe et al. 1996). The potential searched volume $\left(F, \mathrm{ml}\right.$ ind. $\left.{ }^{-1} \mathrm{~h}^{-1}\right)$ during ambush feeding can be calculated by the model of Jonsson \& Tiselius (1990): $F=A \times U$, where $A$ is the cross-sectional area $\left(\mathrm{cm}^{2}\right)$ of the capture volume in which the copepod detects and attacks the prey and $U$ is the copepod sinking velocity $\left(\mathrm{cm} \mathrm{h}^{-1}\right)$. In adult female $A$. tonsa the parameter $A$ is mainly dependent on prey size and includes various detection abilities of the copepod and various escape capabilities of the prey (Jonsson \& Tiselius 1990). We defined $A$ as a rectangle with length equals twice the length of the first antenna and width equals the distal, longest, forward-projected seta on the first antenna ( $A=2 \times$ antenna length $\times$ maximal setal length). The points where A. tonsa have been found to successfully capture prey are concentrated anterior to the first antennae (Jonsson \& Tiselius 1990), which is why we chose only the forward-projecting setae. This estimation is conservative because it excludes the area sensed by remote detection (Jonsson \& Tiselius 1990, Broglio et al. 2001). The lengths of the first antenna, the distal seta and the prosome of 5 to 7 individuals at each copepodite stage were measured under a stereomicroscope. Sinking velocity was determined from the video recordings.

Statistical analysis. Two-way factorial ANOVAs followed by Tukey-Kramer post hoc comparisons were used for testing the effect of copepodite stage and food condition (food concentration and presence/absence of food) on the behavioural components. Mean distance or duration time displayed by single individuals in a given treatment were used as the dependent variable. Proportions of time spent feeding at various food concentrations were arcsine transformed (Sokal \& Rohlf 1995) prior to analyses. Analysis of covariance (ANCOVA) was used to compare mean jumping distance for each of the food conditions (food concentration or presence/absence of food), using prosome length as the covariate. Effects of food treatments on sinking velocity were also tested with ANCOVA, using $\log _{10}$-transformed prosome lengths as the covariate. All statistical analyses were performed using the SPSS (v.10) package.

\section{RESULTS}

\section{Behavioural observations}

All copepodite stages of Acartia clausi exhibited a jump-sink motility pattern, spending most of their time (60 to $97 \%$ ) sinking, but with varying degrees of feeding activity in response to food conditions (Table 1). The suspension-feeding behaviour appeared to be the same throughout development: the thoracic legs extended in association with the movement of mouth parts as observed for adult females by Rosenberg (1980). The time spent suspension feeding is therefore equivalent to the time spent swimming. We observed that the feeding-bouts in young copepodites (CI and CII) often occurred directly after a jump, whereas in older stages they usually occurred following passive sinking events.

Filtered seawater rarely induced feeding-bouts in late stages ( 0 to $1 \%$; CIV to adults), whereas early stages (CI to CIII) exhibited clear feeding-bouts, 6 to $16 \%$ of their time (Table 1 ). When offered food, all copepodite stages showed feeding-bouts, but the time allocated to feeding varied significantly among stages and food concentrations (Table 2). Feeding time was significantly longer in 60 and 500 cells ml$^{-1}$, and CI copepodites spent significantly more time feeding than adult females (Table 2 ) at 60 cells $\mathrm{ml}^{-1}$. CV copepodites and adults tended to reduce feeding activity in 60 cells $\mathrm{ml}^{-1}$.

Feeding-bout frequencies were significantly affected by food concentration, but not by stage (Table 2). The frequency was highest in 500 cells ml-1 and lowest in 2000 cells $\mathrm{ml}^{-1}$, and there was a tendency of lower frequencies at 60 cells ml ${ }^{-1}$ compared to 500 cells ml ${ }^{-1}$ for CV copepodites and adults (Fig. 1a). Mean duration of feeding-bouts was significantly longer at lower food 
Table 1. Acartia clausi. Time budgets of the motility pattern of copepodites and adults in filtered seawater and suspension of the diatom Thalassiosira weissflogii at 60,500 and 2000 cells ml$^{-1}$. n: number of individuals observed

\begin{tabular}{|c|c|c|c|c|c|c|}
\hline \multirow[t]{2}{*}{ Food treatment } & \multirow{2}{*}{$\begin{array}{c}\text { Stage } \\
\text { or sex } \\
\text { of } A \text {. clausi }\end{array}$} & \multirow{2}{*}{$\begin{array}{c}\text { Mean } \\
\text { prosome } \\
\text { length }(\mu \mathrm{m})\end{array}$} & \multirow[t]{2}{*}{$\mathrm{n}$} & \multicolumn{3}{|c|}{ Mean percentage of each behavioural event $( \pm \mathrm{SD}$} \\
\hline & & & & Sink & Jump & Swim \\
\hline \multirow[t]{7}{*}{ Filtered seawater } & Male & 782 & 6 & $97.1( \pm 0.6)$ & $2.7( \pm 0.6)$ & $0.1( \pm 0.3)$ \\
\hline & Female & 826 & 5 & $95.9( \pm 1.1)$ & $4.1( \pm 1.1)$ & 0.0 \\
\hline & CV & 697 & 5 & $96.5( \pm 0.9)$ & $3.5( \pm 0.9)$ & 0.0 \\
\hline & CIV & 577 & 4 & $96.0( \pm 1.4)$ & $3.2( \pm 1.1)$ & $0.8( \pm 0.6)$ \\
\hline & CIII & 477 & 5 & $89.2( \pm 1.1)$ & $3.4( \pm 0.9)$ & $7.4( \pm 1.2)$ \\
\hline & CII & 423 & 4 & $90.8( \pm 4.9)$ & $2.8( \pm 0.7)$ & $6.4( \pm 5.0)$ \\
\hline & $\mathrm{CI}$ & 310 & 4 & $80.7( \pm 11.3)$ & $3.3( \pm 0.2)$ & $16.0( \pm 11.1)$ \\
\hline \multirow[t]{7}{*}{60 cells Thalassiosira $\mathrm{ml}^{-1}$} & Male & 776 & 4 & $78.5( \pm 8.2)$ & $3.7( \pm 0.9)$ & $17.8( \pm 9.0)$ \\
\hline & Female & 788 & 4 & $78.6( \pm 12.2)$ & $3.4( \pm 0.8)$ & $18.0( \pm 12.5)$ \\
\hline & CV & 744 & 4 & $79.5( \pm 7.1)$ & $2.9( \pm 0.6)$ & $17.6( \pm 6.6)$ \\
\hline & CIV & 646 & 5 & $69.2( \pm 8.1)$ & $2.8( \pm 0.5)$ & $28.0( \pm 8.2)$ \\
\hline & CIII & 526 & 4 & $74.7( \pm 8.4)$ & $2.9( \pm 0.4)$ & $22.5( \pm 8.4)$ \\
\hline & $\mathrm{CII}$ & 423 & 3 & $74.2( \pm 6.8)$ & $2.4( \pm 1.5)$ & $23.4( \pm 7.1)$ \\
\hline & $\mathrm{CI}$ & 359 & 4 & $61.8( \pm 11.3)$ & $2.5( \pm 0.8)$ & $35.7( \pm 10.6)$ \\
\hline \multirow[t]{7}{*}{500 cells Thalassiosira $\mathrm{ml}^{-1}$} & Male & 846 & 3 & $65.4( \pm 5.0)$ & $2.6( \pm 0.6)$ & $32.0( \pm 4.5)$ \\
\hline & Female & 851 & 5 & $74.0( \pm 5.8)$ & $4.6( \pm 1.7)$ & $21.4( \pm 6.5)$ \\
\hline & $\mathrm{CV}$ & 790 & 5 & $69.7( \pm 3.9)$ & $2.7( \pm 1.0)$ & $27.6( \pm 3.7)$ \\
\hline & CIV & 673 & 4 & $69.3( \pm 11.6)$ & $2.6( \pm 0.4)$ & $28.1( \pm 11.5)$ \\
\hline & CIII & 574 & 5 & $75.4( \pm 5.4)$ & $2.8( \pm 0.6)$ & $21.8( \pm 5.5)$ \\
\hline & CII & 496 & 3 & $69.5( \pm 9.6)$ & $2.3( \pm 0.7)$ & $28.2( \pm 9.3)$ \\
\hline & $\mathrm{CI}$ & 374 & 5 & $60.1( \pm 8.6)$ & $2.4( \pm 0.8)$ & $37.5( \pm 9.1)$ \\
\hline \multirow[t]{7}{*}{2000 cells Thalassiosira $\mathrm{ml}^{-1}$} & Male & 776 & 4 & $87.4( \pm 7.0)$ & $2.4( \pm 0.9)$ & $10.3( \pm 6.4)$ \\
\hline & Female & 782 & 5 & $89.3( \pm 4.1)$ & $3.8( \pm 1.1)$ & $6.9( \pm 3.9)$ \\
\hline & CV & 744 & 4 & $84.7( \pm 2.7)$ & $3.9( \pm 1.6)$ & $11.4( \pm 3.6)$ \\
\hline & CIV & 610 & 5 & $87.5( \pm 4.6)$ & $3.7( \pm 0.7)$ & $8.7( \pm 4.7)$ \\
\hline & CIII & 528 & 5 & $85.5( \pm 2.7)$ & $2.5( \pm 0.7)$ & $12.0( \pm 2.5)$ \\
\hline & CII & 427 & 3 & $82.5( \pm 5.6)$ & $2.6( \pm 0.5)$ & $14.9( \pm 6.0)$ \\
\hline & $\mathrm{CI}$ & 359 & 3 & $86.3( \pm 8.9)$ & $2.4( \pm 1.1)$ & $11.3( \pm 8.1)$ \\
\hline
\end{tabular}

concentrations due to longer feeding-bouts in younger stages at 60 and 500 cells $\mathrm{ml}^{-1}$, even though the interaction between stages and food concentration was not significant (Fig. 1b, Table 2). Feeding-bout duration declined with body weight when all data from 60 and 500 cells ml $^{-1}$ were pooled, but this relationship was not found in 2000 cells ml $^{-1}$ (Fig. 2).

There were no significant differences in the frequency of long jumps between stages (Table 1). Long jumps served 2 different purposes depending on the stage. In late stages (CIV to adults) the jumps helped the individual to maintain its vertical position by counteracting the larger sinking distance. In early stages (CI to CIII), which did not sink rapidly, jumps were horizontally oriented and moved the copepod forward. The jumping distance was significantly related to body (prosome) length of copepods (Fig. 3). The distance was significantly longer for copepods in filtered seawater compared to those in algal suspension, while food concentration had no significant effect on the jumping distance (Table 3 ). The jumping distances corresponded to 1.2-1.4 body lengths in filtered sea- water and to $0.7-1.2$ in food suspensions, excluding CI and adult males (Fig. 4a). The jumping distance of CI copepodites was significantly shorter ( 0.6 to 0.7 body lengths) and that of adult males significantly longer (1.3 to 1.9 body lengths) than those of other stages, regardless of the presence/absence of food (Fig. 4a; Tukey-Kramer test, $\mathrm{p}<0.05$ ).

The jump frequency was significantly affected by food treatments, but not by stage (Fig. 5a, Table 2). Although adult males showed frequent jumps in the 60 cells $\mathrm{ml}^{-1}$ treatment, they generally jumped less than other stages, including females (Fig. 5a; TukeyKramer test, $p<0.05$ ). Except for adult males, the jump frequencies were consistently higher in filtered seawater than in the treatments of 60 and 500 cells ml ${ }^{-1}$

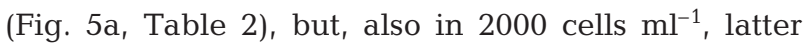
stages (CIV to adults) jumped more frequently than those in 60 and 500 cells ml $^{-1}$ (Tukey-Kramer test, $p<0.05)$. Short jumps were limited to copepodite stages older than CIV, and were significantly more common in adult females (Fig. 5b; Tukey-Kramer test, $\mathrm{p}<0.05)$. 
Table 2. Acartia clausi. Results of 2-way ANOVAs for effects of copepodite stage (Stage), food concentration (Diatom), and food treatment (Food: no food and food) on various behavioural parameters. ${ }^{*}$ Significant effects, $\mathrm{p}<0.05$

\begin{tabular}{|c|c|c|c|c|c|}
\hline Variable & Effect & df & $F$ & $\mathrm{p}$ & Post hoc test (Tukey-Kramer test, $\mathrm{p}<0.05$ ) \\
\hline $\begin{array}{l}\text { Proportion spent } \\
\text { in feeding-bouts }\end{array}$ & $\begin{array}{l}\text { Stage } \\
\text { Diatom } \\
\text { Stage } \times \text { Diatom }\end{array}$ & $\begin{array}{r}6 \\
2 \\
12\end{array}$ & $\begin{array}{r}2.97 \\
41.09 \\
1.10\end{array}$ & $\begin{array}{l}0.0126^{*} \\
<0.0001^{*} \\
0.38\end{array}$ & $\begin{array}{l}\text { CI }>\text { adult female } \\
60,500 \text { cells ml }{ }^{-1}>2000 \text { cells ml }^{-1}\end{array}$ \\
\hline $\begin{array}{l}\text { Frequency of } \\
\text { feeding-bouts }\end{array}$ & $\begin{array}{l}\text { Stage } \\
\text { Diatom } \\
\text { Stage } \times \text { Diatom }\end{array}$ & $\begin{array}{r}6 \\
2 \\
12\end{array}$ & $\begin{array}{r}0.33 \\
26.34 \\
0.73\end{array}$ & $\begin{array}{l}0.92 \\
<0.0001^{*} \\
0.72\end{array}$ & 500 cells ml ${ }^{-1}>60$ cells ml $^{-1}>2000$ cells ml$^{-1}$ \\
\hline $\begin{array}{l}\text { Duration of } \\
\text { feeding-bouts }\end{array}$ & $\begin{array}{l}\text { Stage } \\
\text { Diatom } \\
\text { Stage } \times \text { Diatom }\end{array}$ & $\begin{array}{r}6 \\
2 \\
12\end{array}$ & $\begin{array}{l}8.38 \\
9.39 \\
0.08\end{array}$ & $\begin{array}{l}<0.0001^{*} \\
0.0003^{*} \\
0.08\end{array}$ & $\begin{array}{l}\text { CI }>\text { CIII-CV, adult female and male, CII > adult female } \\
60,500 \text { cells ml }{ }^{-1}>2000 \text { cells ml }\end{array}$ \\
\hline $\begin{array}{l}\text { Frequency of } \\
\text { long jump }\end{array}$ & $\begin{array}{l}\text { Stage }^{\mathrm{b}} \\
\text { Food } \\
\text { Stage } \times \text { Food }\end{array}$ & $\begin{array}{r}5 \\
3 \\
15\end{array}$ & $\begin{array}{l}0.34 \\
5.74 \\
0.79\end{array}$ & $\begin{array}{l}0.89 \\
0.0013^{*} \\
0.68\end{array}$ & Filtered seawater $>60,500$ cells ml $^{-1}$ \\
\hline $\begin{array}{l}\text { Relative sinking } \\
\text { distance }\end{array}$ & $\begin{array}{l}\text { Stage } \\
\text { Food } \\
\text { Stage } \times \text { Food }\end{array}$ & $\begin{array}{r}6 \\
3 \\
18\end{array}$ & $\begin{array}{c}3.12 \\
22.6 \\
1.40\end{array}$ & $\begin{array}{l}0.002^{*} \\
<0.0001^{*} \\
0.15\end{array}$ & $\begin{array}{l}\text { Male }>\text { all other stages } \\
\text { Filtered seawater }>2000 \text { cells ml }{ }^{-1}>60,500 \text { cells ml }^{-1}\end{array}$ \\
\hline
\end{tabular}

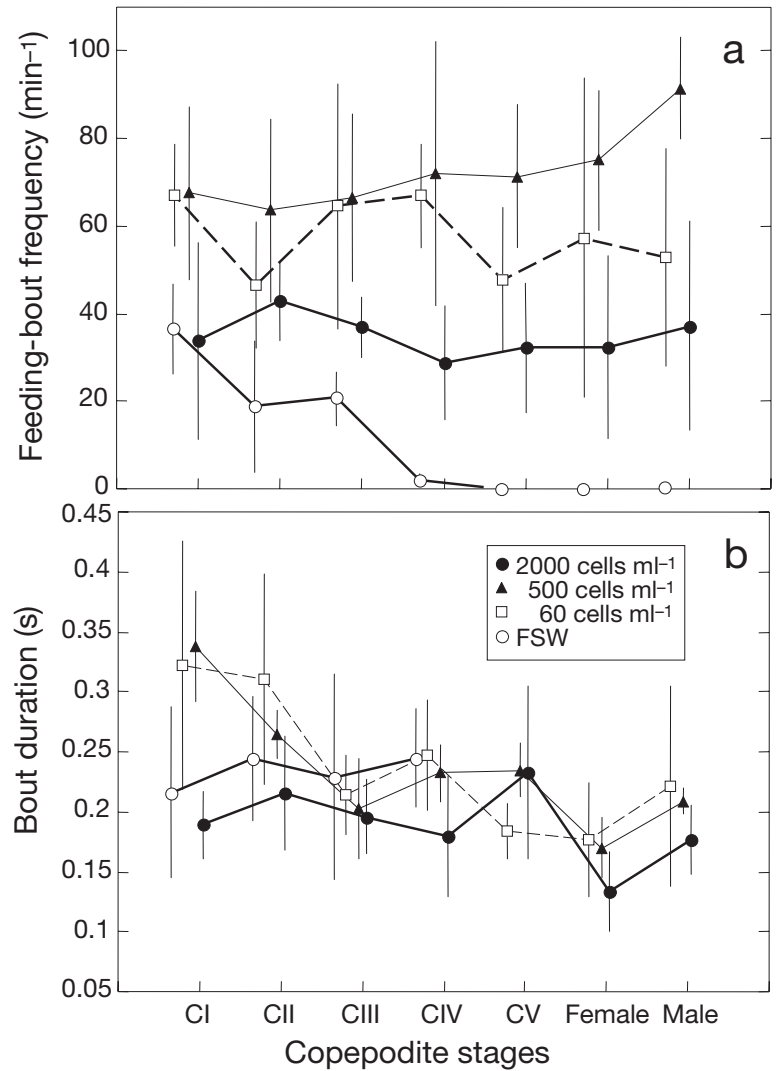

Fig. 1. Acartia clausi. (a) Feeding-bout frequency and (b) bout duration of copepodites and adults in filtered seawater (FSW) and various concentrations of Thalassiosira weissflogii. Vertical bars are \pm SD
Sinking velocity increased with body length (Fig. 6), but no effect of food was evident (Table 3). Relative sinking distances (normalised to prosome lengths), however, varied significantly between food treatments and between stages (Table 2). Adult males sank significantly further than other stages (Fig. 4b; TukeyKramer test, $\mathrm{p}<0.05$ ), and filtered seawater induced the furthest sinking.

\section{Feeding experiments}

Clearance was highest in 500 cells $\mathrm{ml}^{-1}$ and decreased both in 60 and 2000 cells ml $^{-1}$ (Table 4). Weightspecific ingestion approached $100 \% \mathrm{~d}^{-1}$ in 500 to 2000 cells ml ${ }^{-1}$ for both stages ( 70 to $120 \% \mathrm{~d}^{-1}$ ). In both stages, food-gathering efficiencies varied according to food concentration. Although CI copepodites spent a longer time feeding than adult females at all food concentrations, the food-gathering efficiencies of CI copepodites were at the same or below the level of adult females (Table 4).

\section{Estimation of search volume in ambush feeding}

The lengths of antennae and distal setae were both linearly related to body length, and slightly shorter in males (Fig. 7). Multiplying the cross-sectional area estimated from Fig. 7 with sinking velocities (Fig. 6) for 


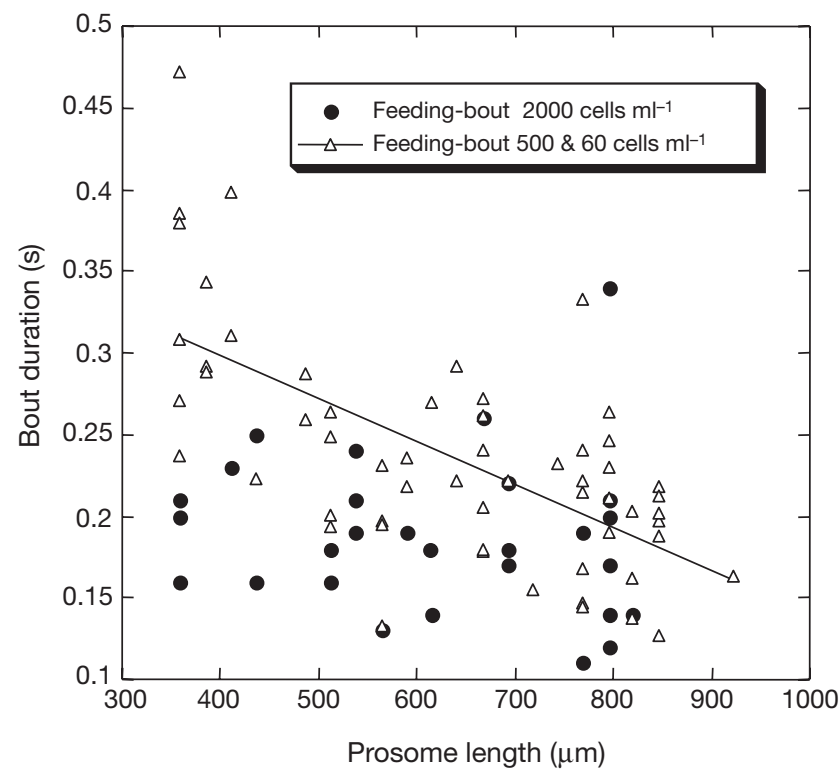

Fig. 2. Acartia clausi. Relationships between prosome length (PL) and feeding-bout duration (FBD) in 2000 cells $\mathrm{ml}^{-1}$ or 60 and 500 cells ml $^{-1}$ (pooled) of Thalassiosira weissflogii. The regression for the 60 and 500 cells ml ${ }^{-1}$ is FBD $=0.403-$ 0.00026 PL $\left(n=58, R^{2}=0.42, p<0.0001\right)$

each stage gives the potential search volume in ambush-feeding mode for the different stages (Fig. 8, Line a). The model shows that the potential search volume increases linearly with body weight, using the length-weight regression of Durbin \& Durbin (1978). The weight-specific search volume, however, ranges from 1.35 to 2.05 , with the highest values for adult

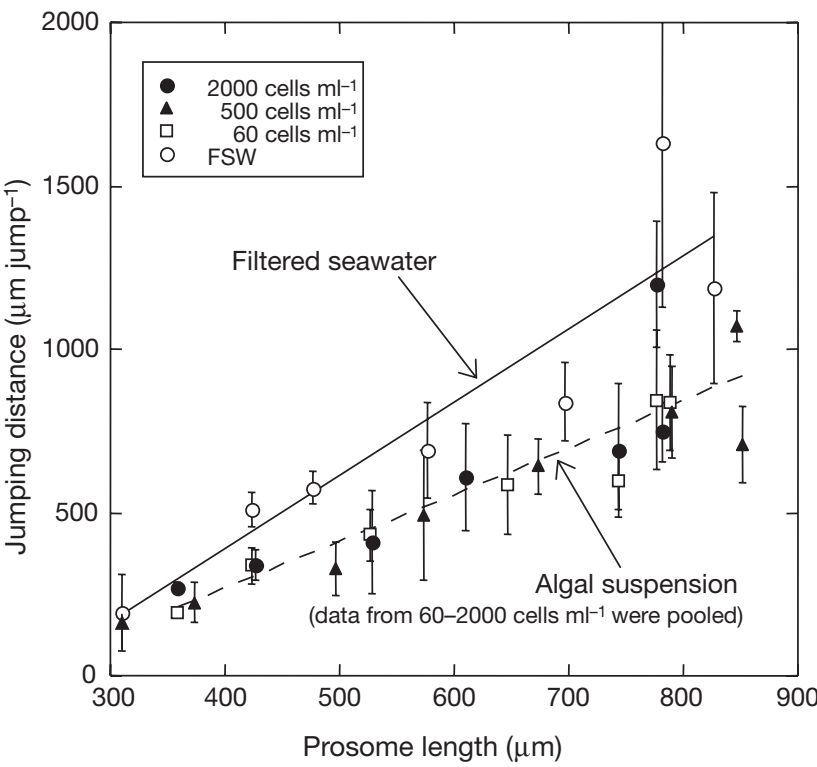

Fig. 3. Acartia clausi. Relationships between prosome length (PL) and jumping distance (JD) of copepodites and adults in filtered seawater (FSW) and various concentrations of Thalassiosira weissflogii. Vertical bars are $\pm \mathrm{SD}$. The regression line for FSW is JD $=-501.0+2.25 \mathrm{PL}\left(\mathrm{n}=7, \mathrm{R}^{2}=0.83, \mathrm{p}=0.0046\right)$. The regression line for the pooled algal suspensions is JD = $-308.8+1.44$ PL $\left(\mathrm{n}=21, \mathrm{R}^{2}=0.86, \mathrm{p}<0.001\right)$ and includes observations for food concentrations of 60,500 and 2000 cells $\mathrm{ml}^{-1}$. No statistical difference in jumping distance was found among food concentrations (see Table 3)

females (Fig. 8, Line b). The weight-specific search volume in CI copepodites was $<70 \%$ of that in adult females.

Table 3. Acartia clausi. Results of ANCOVA test for effects of food conditions on behavioural parameter of copepodite stages. Prosome length used as a covariate. Interaction terms have been removed from the analysis, since no significant differences in slopes among food conditions were found. *Significant effects, $\mathrm{p}<0.05$

\begin{tabular}{|c|c|c|c|c|}
\hline Source & SS & df & $F$ & $\mathrm{p}$ \\
\hline \multicolumn{5}{|c|}{ Effects of presence/absence of diatom on jumping distance } \\
\hline Presence/absence of diatom & 330676.7 & 1 & 16.59 & $0.0004^{*}$ \\
\hline Prosome length & 2644039.8 & 1 & 132.64 & $<0.0001^{*}$ \\
\hline Error & 498393.9 & 25 & & \\
\hline \multicolumn{5}{|l|}{ Effects of diatom concentration on jumping distance } \\
\hline Diatom concentrations & 11626.2 & 2 & 0.51 & 0.683 \\
\hline Prosome length & 1568336.7 & 1 & 138.11 & $<0.0001^{*}$ \\
\hline Error & 193050.0 & 17 & & \\
\hline \multicolumn{5}{|l|}{ Effects of food treatments on sinking rate ${ }^{a}$} \\
\hline Food treatments (FSW, 60, 500, 2000 cells ml $\left.{ }^{-1}\right)$ & 0.061 & 3 & 1.931 & 0.129 \\
\hline Prosome length & 3.352 & 1 & 337.58 & $<0.0001^{*}$ \\
\hline Error & 1.172 & 113 & & \\
\hline
\end{tabular}



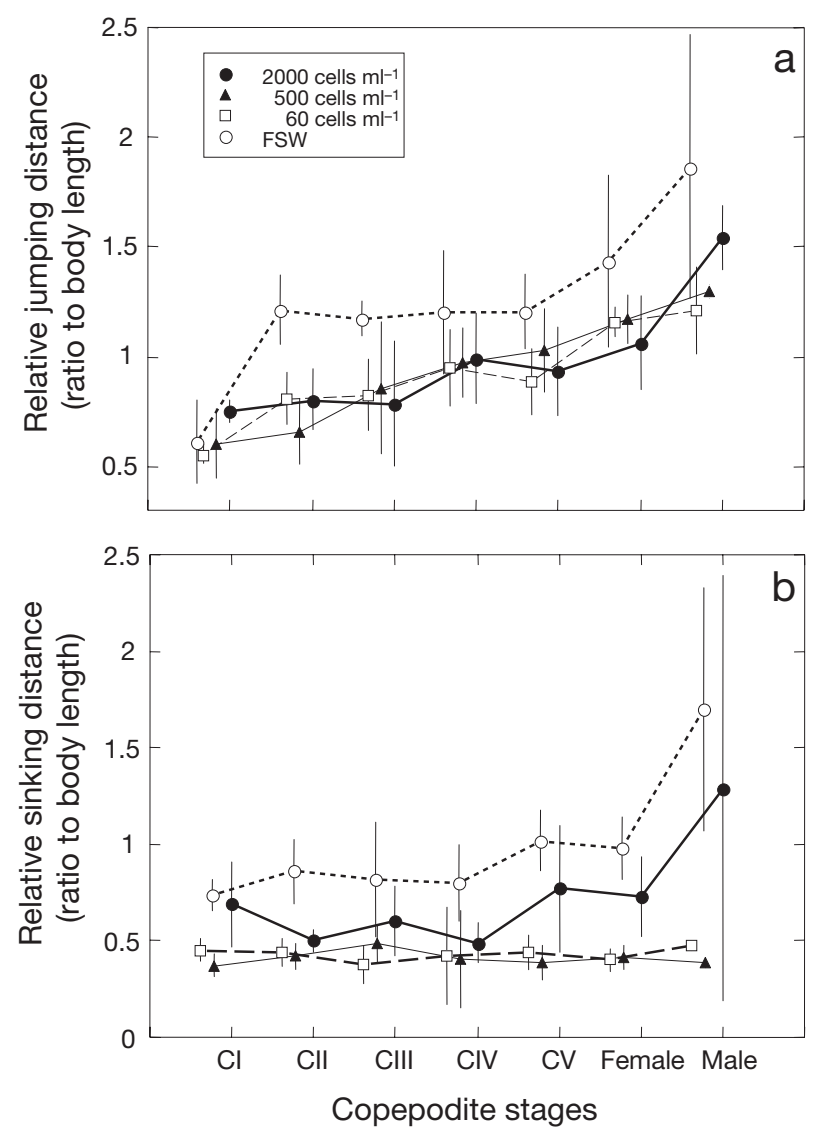

Fig. 4. Acartia clausi. Relative distance (normalised to body length) of (a) jumping and (b) sinking for copepodites and adults in filtered seawater (FSW) and various concentrations of Thalassiosira weissflogii. Vertical bars are $\pm \mathrm{SD}$

\section{DISCUSSION}

All copepodite stages of Acartia clausi exhibited a jump-sink behaviour, which agrees with previous reports for females of Acartia spp. including A. clausi (Gauld 1966, Jonsson \& Tiselius 1990, Tiselius \& Jonsson 1990, Saiz \& Alcaraz 1992, Tiselius 1992). The jump-sink behaviour has also been reported in nauplii of A. tonsa (Buskey 1994, Titelman \& Kiørboe 2003a), and, although the jump frequency is higher in nauplii (A. tonsa; 88 to $183 \mathrm{~min}^{-1}$ in filtered seawater) than that in copepodites (30 to $45 \mathrm{~min}^{-1}$ in filtered seawater, Fig. 5a), it appears to be a consistent feature throughout the development of Acartia spp. When offered a suspension of diatoms, all copepodite stages reduced jumping distance and generally also jump frequency (Figs. 3 \& 5). A decreased jumping distance in food was also reported in adult female $A$. clausi (Piontkovskii \& Petipa 1976); this probably serves as an adaptation to remain in food patches and also to lower predation risk. In contrast, longer and more frequent jumps in

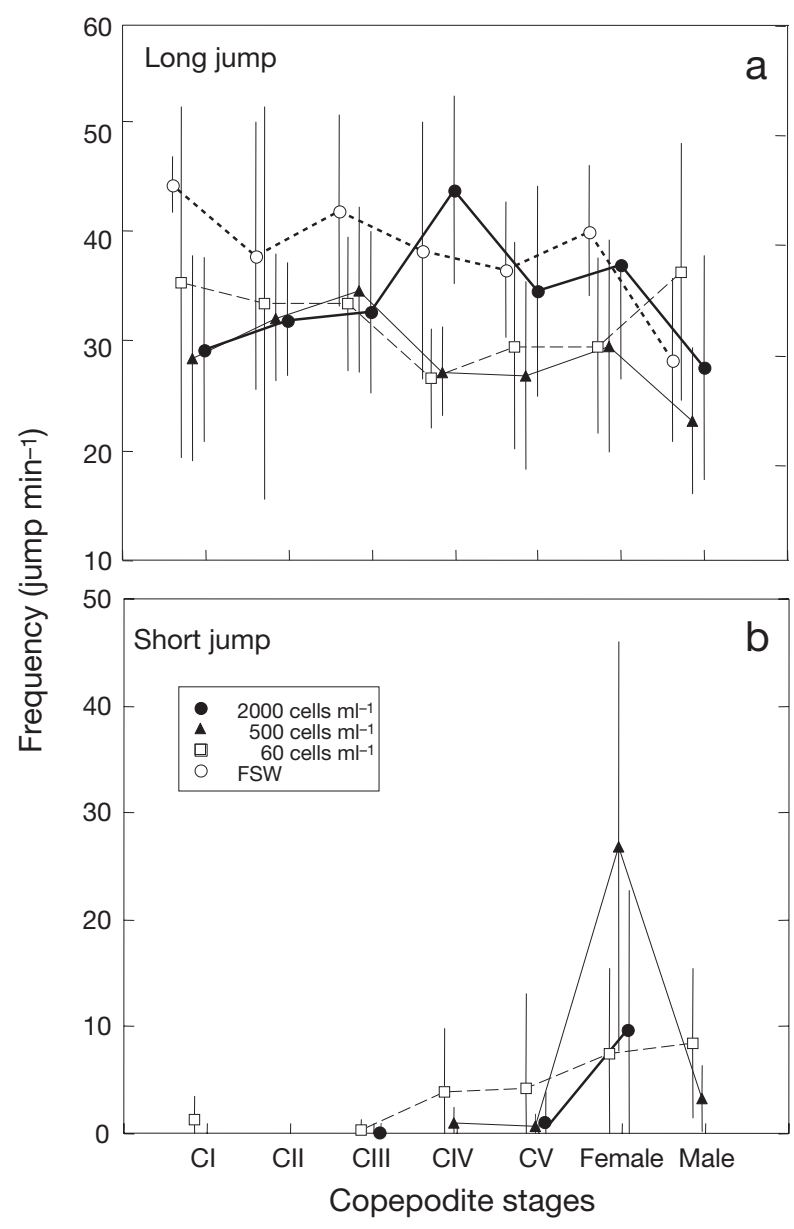

Fig. 5. Acartia clausi. Frequencies of (a) long jumps and (b) short jumps of copepodites and adults in filtered seawater (FSW) and various concentrations of Thalassiosira weissflogii. Vertical bars are $\pm \mathrm{SD}$

filtered seawater is a behaviour adaptive to searching for food patches in the field.

The time allocated to suspension feeding varied depending on the food concentration and stage (Table 1). Time spent feeding was highest in 500 cells $\mathrm{ml}^{-1}$ and lowest in 2000 cells $\mathrm{ml}^{-1}$, regardless of copepodite stage, and the feeding activity reflected the clearance rates estimated in feeding experiments (Table 4), as also reported for adult female Acartia tonsa (Kiørboe et al. 1996). At low food concentrations, however, clear ontogenetic differences were observed. CI to CIV copepodites engaged longer in suspension feeding than latter stages (CV to adults). Clearance at 60 cells $\mathrm{ml}^{-1}$ was lower both in CI copepodites and adult females (Table 4), indicating the existence of a lower feeding threshold throughout copepodite development. A feeding threshold has been found in adult females of Acartia spp. (Reeve \& Walter 1977, Kiørboe et al. 1985, Paffenhöfer \& Stearns 1988, Wlodarczyk et 


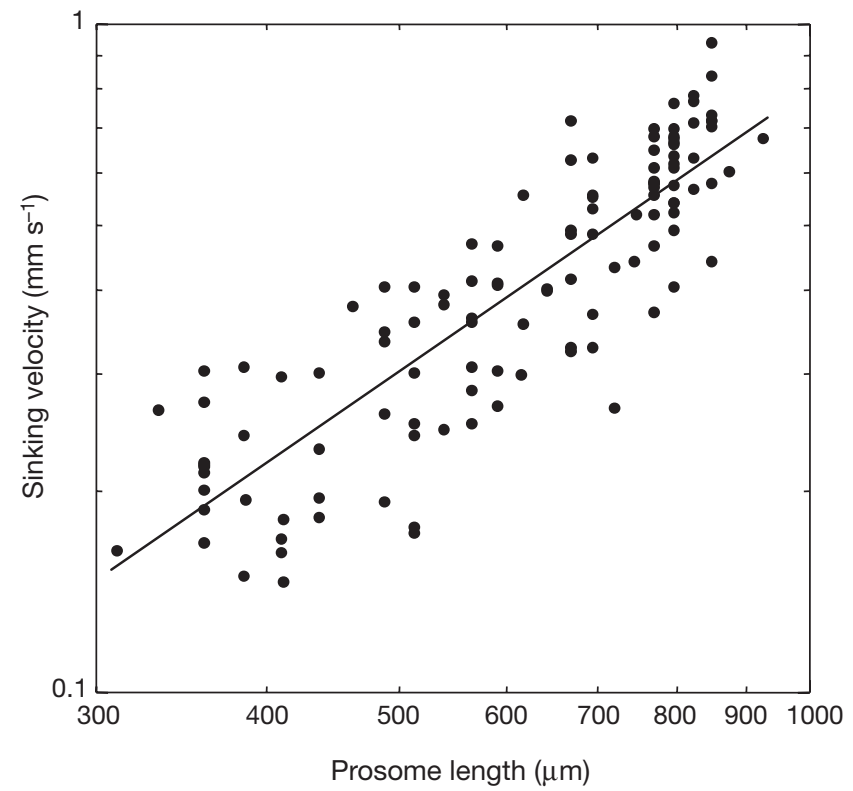

Fig. 6. Acartia clausi. Relationships between prosome length (PL) and sinking velocity (SV) in filtered seawater and various concentrations of Thalassiosira weissflogii. Note that $x$ - and $y$ axes are logarithmic. All data from the 4 food treatments (60, 500 and 2000 cells ml $^{-1}$, and filtered seawater) were pooled for the regression. The regression is $\log _{10}$-transformed $\mathrm{SV}=$ $-4.325+1.41 \times \log _{10}$ PL $\left(n=118, R^{2}=0.746, p<0.0001\right)$

al. 1992), as well as in other calanoid copepods (Corner et al. 1972, Frost 1975, Frost et al. 1983, Price \& Paffenhöfer 1986, Paffenhöfer 1988). In A. tonsa, the lower feeding rate - below the threshold - is the result of a decrease in mouthpart movements (time spent feeding) and a lower fraction of encountered cells being captured (Paffenhöfer \& Stearns 1988). Paffenhöfer \& Stearns' suggestion agrees with the results for adult females in the present study (Table 4). CI copepodites, in contrast, did not decrease their time spent feeding, and the energy conserving hypothesis might not be applicable to early copepodite stages of A. clausi.

Feeding-bouts were slightly longer for CI copepodites at 60 and 500 cells ml $^{-1}$, than at 2000 cells ml $^{-1}$ (Fig. 1b). Small copepodites may need to make longer feeding-bouts to collect sufficient diatoms for a single ingestion event if food concentration is low. Adult females ingested the same number of cells at 500 and 2000 cells $\mathrm{ml}^{-1}$ and were able to compensate for the lower food concentration by increasing activity. Specific ingestion of CI copepodites at 500 cells $\mathrm{ml}^{-1}$ was only $60 \%$ of that in 2000 cells ml $\mathrm{m}^{-1}$ (Table 4 ), suggesting that CI copepodites had an inefficient suspensionfeeding ability. Overall, feeding-bout duration at 60 and 500 cells $\mathrm{ml}^{-1}$ was negatively correlated with body size (Fig. 2), and the efficiency of suspension feeding seems to improve during growth.

Efficient suspension feeding requires a tethering force to anchor the animal when it feeds. The shift from drag to gravity as the tethering force during growth allows a stronger current in heavier animals (Emlet \& Strathmann 1985, Tiselius \& Jonsson 1990). Frequent short jumps associated with feeding-bouts were observed only in later copepodite stages, CIV to adults (Fig. 5b), and they reoriented themselves with respect to the gravitational force to maximise the efficiency of their suspension-feeding current. CI swam more horizontally, probably using drag rather than gravity as a tether force, and were less efficient at anchoring themselves to support a strong feeding current.

The short feeding-bouts in early copepodites (CI to CIII) at 60 cells $\mathrm{ml}^{-1}$ probably indicate that they are just sampling the water for food (Tiselius 1992), and these bouts are also performed in filtered seawater (Table 1, Fig. 1). Late copepodite stages in contrast showed no feeding-bouts in the filtered seawater and may instead search for motile prey in the ambush-feeding mode (Jonsson \& Tiselius 1990, Tiselius \& Jonsson 1990, Kiørboe et al. 1996). The presence of the sample feed-

Table 4. Acartia clausi. Clearance, ingestion rates and specific ingestion of adult female and CI copepodites, determined by feeding experiments. Carbon contents of copepods were assumed to be $43 \%$ of body dry weight. Thalassiosira weissflogii was 79 pg $\mathrm{C}$ cell $^{-1}$ (estimated from Strathmann 1967). Specfic ingestion was calculated by multiplying the $4 \mathrm{~h}$ feeding experiment by 6 (= $24 \mathrm{~h})$. Proportion spent feeding is based on data from behavioural observations (see 'Results' and Table 1). Food-gathering efficiency calculated from specific ingestion divided by fraction of time spent for feeding

\begin{tabular}{|c|c|c|c|c|c|c|}
\hline Stage & $\begin{array}{l}\text { Target diatom } \\
\text { concentration } \\
\left(\text { cells } \mathrm{ml}^{-1} \text { ) }\right.\end{array}$ & $\begin{array}{l}\text { Clearance } \pm \text { SD } \\
\left(\mathrm{ml} \text { ind } .^{-1} \mathrm{~h}^{-1}\right)\end{array}$ & $\begin{array}{l}\text { Ingestion rate } \pm \text { SD } \\
\quad\left(\text { cells ind } .^{-1} \mathrm{~h}^{-1}\right)\end{array}$ & $\begin{array}{c}\text { Specific ingestion } \\
\left(\% \mathrm{~d}^{-1}\right)\end{array}$ & $\begin{array}{l}\text { Propotion spent } \\
\text { feeding }(\%)\end{array}$ & $\begin{array}{c}\text { Food-gathering } \\
\text { efficiency }\end{array}$ \\
\hline \multirow[t]{3}{*}{ Adult female } & 60 & $0.51 \pm 0.38$ & $35.2 \pm 25.7$ & 2 & 18 & 0.1 \\
\hline & 500 & $2.60 \pm 1.26$ & $1316.3 \pm 573.6$ & 90 & 21 & 4.3 \\
\hline & 2000 & $0.70 \pm 0.16$ & $1370.8 \pm 302.3$ & 90 & 7 & 12.9 \\
\hline \multirow[t]{3}{*}{ CI } & 60 & $0.05 \pm 0.03$ & $3.9 \pm 2.6$ & 3 & 36 & 0.1 \\
\hline & 500 & $0.16 \pm 0.02$ & $79.1 \pm 10.4$ & 70 & 37 & 1.9 \\
\hline & 2000 & $0.07 \pm 0.00$ & $140.7 \pm 4.7$ & 120 & 11 & 10.9 \\
\hline
\end{tabular}



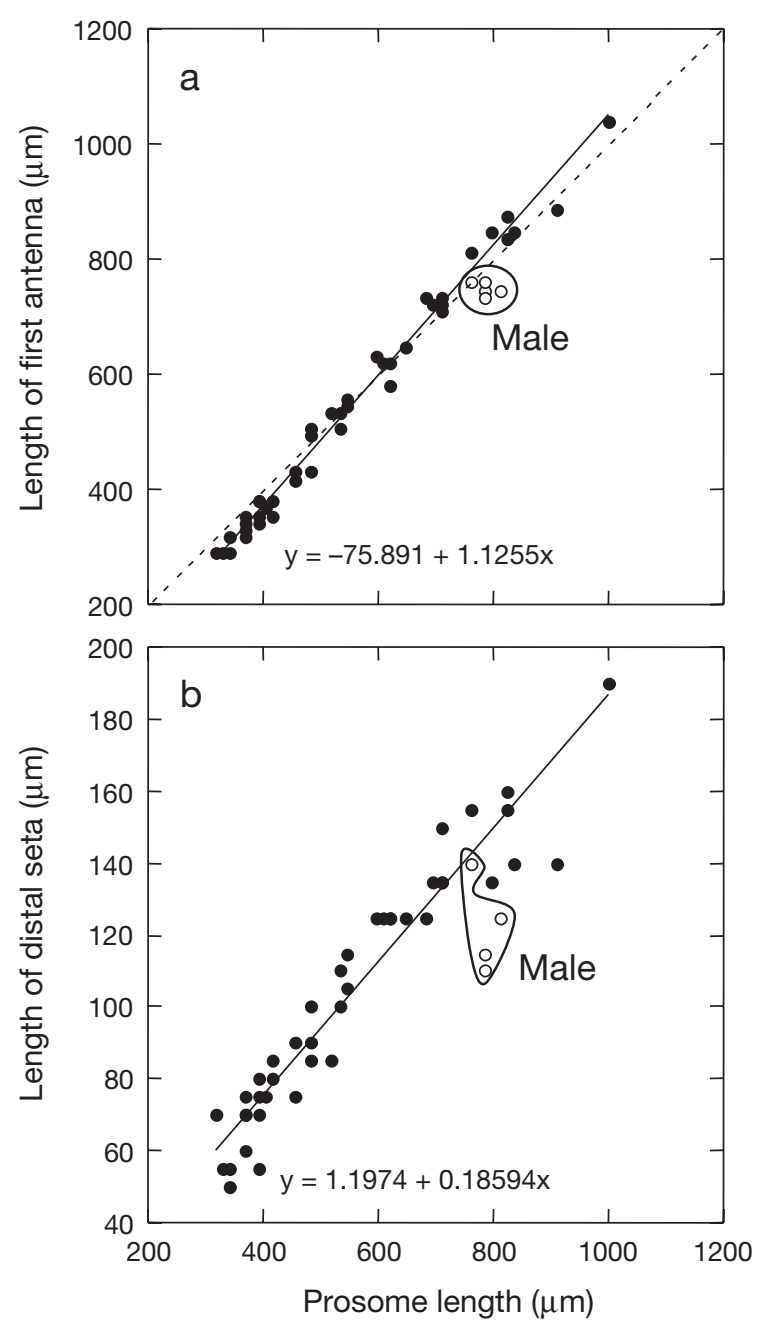

Fig. 7. Acartia clausi. Relationship between prosome length and length of (a) first antenna and (b) distal seta on the antenna. Values from males are shown with open circles and were not included in regression analysis. Dashed line: $y=x$. Regressions were significant in both cases. First antenna: $\mathrm{p}<0.0001, \mathrm{R}^{2}=$ $0.99, \mathrm{n}=42$; distal seta: $\mathrm{p}<0.0001, \mathrm{R}^{2}=0.92, \mathrm{n}=42$

ing-bouts in early copepodite stages is probably due to their low efficiency of ambush feeding. Weight-specific search volume in CI copepodites was only about $70 \%$ of that in adult females (Fig. 8), and the smaller individuals apparently depended more on suspension feeding than on ambush feeding regardless of food availability.

Predatory feeding on ciliates or copepod nauplii has been shown in nauplii and early copepodite stages of Acartia spp. (Landry 1978, Stoecker \& Egloff 1987), but Landry (1978) reported that early copepodite stages (CI and CII) of A. clausi did not prey on conspecific nauplii when alternate food (phytoplankton) was offered. In contrast, later stages switched to predatory feeding under the same conditions (Landry 1978).

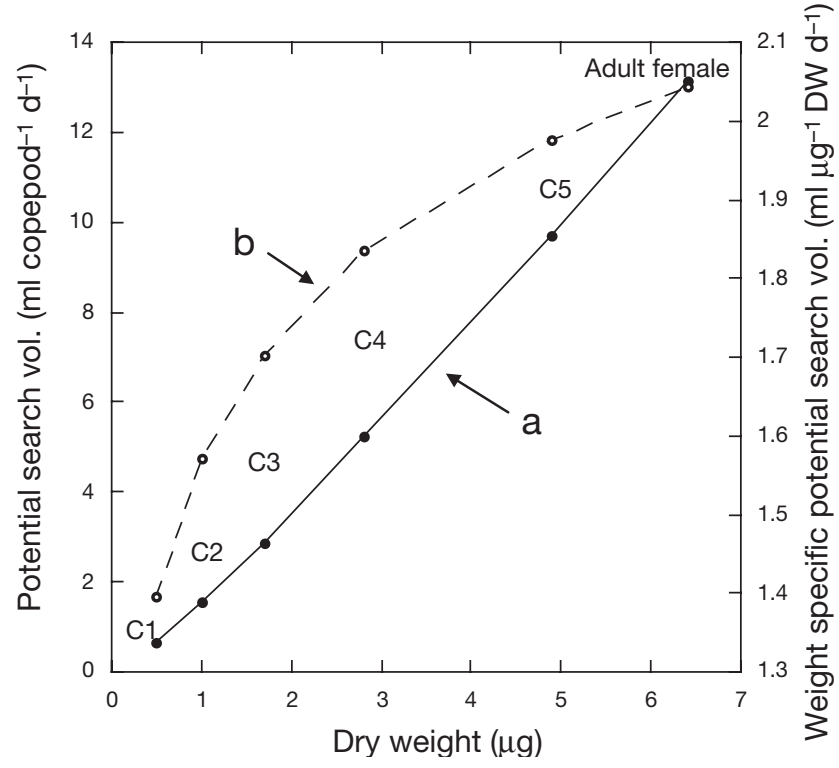

Fig. 8. Acartia clausi. a (solid line): ontogenetic change in potential search volume by ambush feeding, calculated from the cross-sectional area multiplied by sinking velocity (see 'Results'). b (dashed line): relationship between body weight and weight-specific potential search volume. Note that no time budgets are included here

Constant feeding-bouts for sampling in early copepodite stages Acartia clausi indicate a costly foraging strategy, which may not be sustainable unless food conditions are favourable, e.g. in a phytoplankton patch. Young copepodites of Acartia spp. tend to occur in the upper part of the water column (Landry 1978, Ueda 1987), and A. clausi CI copepodites have been observed to maintain a close association with the chlorophyll maximum throughout the diel cycle (Harris 1988, Titelman \& Fiksen 2004). In the chlorophyll maximum, early copepodite stages can suspension feed continuously and sustain their relatively high metabolic requirements.

Our results confirm that foraging behaviour in Acartia clausi is different in early and late copepodite stages. Based on a food encounter model, Titelman \& Kiørboe (2003a) concluded that nauplii of $A$. tonsa rely on motile food. Predation on motile prey is well established in adult female Acartia spp. (e.g. Stoecker \& Egloff 1987, Wiadnyana \& Rassoulzadegan 1989), as is their switching behaviour, using either suspension or ambush feeding according to food availability (Jonsson \& Tiselius 1990, Kiørboe et al. 1996, Gismervik \& Andersen 1997). Judging from the jump frequency and sinking velocity, ambush feeding can be divided into 2 phases. Frequent jumps of nauplii serve to avoid local food depletion (Titelman \& Kiørboe 2003a), and they search the water column by means of jumping. Copepodite stages, in contrast, scan the water column while 
they are sinking and jump much less frequently (Jonsson \& Tiselius 1990). This indicates that the ambushfeeding efficiency of Acartia spp. is greatly improved through the transformation from nauplius to copepodite. This efficiency relies on 2 factors, both of which change during ontogeny: sinking velocity, which increases due to increased body weight, and jumping capability, using the first antenna and urosome, which compensates for the larger sinking distance. Since CI copepodites jump less and sink slowly, these small animals largely have to depend on suspension feeding.

Based on the balance between gravitational and drag force on zooplankton in the water column, Emlet \& Strathmann (1985) predicted that behaviour and the energetic cost in swimming of zooplankton should change at a body length of about $0.6 \mathrm{~mm}$. Tiselius \& Jonsson (1990) found a strong shift in the efficiency of suspension feeding in the same size range. Our observations agree with these predictions, since many behavioural parameters such as feeding-bouts and jump frequency notably change between CIII and CIV copepodites, corresponding to about $0.6 \mathrm{~mm}$ (in prosome length). Therefore, we suggest that increased body weight will enhance the foraging efficiency during both suspension (by tethering force) and ambush feeding (by sinking) and that body weight is an important factor for optimal feeding in Acartia clausi.

Acknowledgements. We gratefully acknowledge the assistance of the staff at Kristineberg Marine Research Station. D. Calliari, L. Rodríguez-Graña and P. Thor gave valuable support and comments during the course of the study. Financial support was provided by a JSPS Postdoctoral Fellowship for Research Abroad (2002 fiscal year) to K.T. and by the Wåhlströms Foundation to P.T.

\section{LITERATURE CITED}

Allan JD, Richman R, Heinle DR, Huff R (1977) Grazing in juvenile stages of some estuarine calanoid copepods. Mar Biol 43:317-331

Björnberg TKS (1986) Aspects of the appendages in development. Syllogeus 58:51-66

Broglio E, Johansson M, Jonsson PR (2001) Trophic interaction between copepods and ciliates: effects of prey swimming behaviour on predation risk. Mar Ecol Prog Ser 220:179-186

Buskey EJ (1994) Factors affecting feeding selectivity of visual predators on the copepod Acartia tonsa: locomotion, visibility and escape responses. Hydrobiologia 292/293:447-453

Corner EDS, Head RN, Kilvington CC (1972) On the nutrition and metabolism of zooplankton. VIII. The grazing of Biddulphia cells by Calanus helgolandicus. J Mar Biol Assoc UK 52:847-861

Dexter BL (1986) Developmental grazing capabilities of Pseudocalanus sp. and Acartia clausi (CI to adult): a comparative study of feeding. Syllogeus 58:547-551

Durbin EG, Durbin AG (1978) Length and weight relationships of Acartia clausi in Narragansett Bay, Rhode Island. Limnol Oceanogr 23:958-969

Emlet RB, Strathmann RR (1985) Gravity, drag and feeding currents of small zooplankton. Science 228:1016-1017

Frost BW (1972) Effects of size and concentration of food particles on the feeding behavior of the marine planktonic copepod Calanus pacificus. Limnol Oceanogr 17:805-815

Frost BW (1975) A threshold feeding behavior in Calanus pacificus. Limnol Oceanogr 20:263-266

Frost BW, Landry MR, Hassett RP (1983) Feeding behavior of large calanoid copepods Neocalanus cristatus and N. plumchrus from the subarctic Pacific Ocean. Deep-Sea Res 30:1-13

Gauld DT (1966) The swimming and feeding of planktonic copepods. In: Barns H (ed) Contemporary studies in marine science. George Allen \& Unwin, London, p 313-334

Gismervik I, Andersen T (1997) Prey switching by Acartia clausi: experimental evidence and implications of intraguild predation assessed by a model. Mar Ecol Prog Ser 157:247-259

Harris RP (1988) Interactions between diel vertical migratory behaviour of marine zooplankton and the subsurface chlorophyll maximum. Bull Mar Sci 43:663-684

Jiang H, Paffenhöfer GA (2004) Relation of behavior of copepod juveniles to potential predation by omnivorous copepods: an empirical-modeling study. Mar Ecol Prog Ser 278: 225-239

Jonsson PR, Tiselius P (1990) Feeding behaviour, prey detection and capture efficiency of the copepod Acartia tonsa feeding on planktonic ciliates. Mar Ecol Prog Ser 60:35-44

Kiørboe T, Møhlenberg F, Hamburger K (1985) Bioenergetics of the planktonic copepod Acartia tonsa: relation between feeding, egg production and respiration, and composition of specific dynamic action. Mar Ecol Prog Ser 26:85-97

Kiørboe T, Saiz E, Viitasalo M (1996) Prey switching behaviour in the planktonic copepod Acartia tonsa. Mar Ecol Prog Ser 143:65-75

Landry MR (1978) Population dynamics and production of a planktonic marine copepod, Acartia clausi, in a small temperate lagoon on San Juan Island, Washington. Int Rev Gesamten Hydrobiol 63:77-119

Mauchline J (1998) The biology of calanoid copepods. Adv Mar Biol 33:1-710

Nival P, Nival S (1976) Particle retention efficiencies of an herbivorous copepod, Acartia clausi (adult and copepodite stages): effects on grazing. Limnol Oceanogr 21:24-38

Osgood KE, Frost BW (1994) Ontogenetic diel behaviors of the marine planktonic copepods Calanus pacificus and Metridia lucens. Mar Ecol Prog Ser 104:13-25

Paffenhöfer GA (1988) Feeding rates and behavior of zooplankton. Bull Mar Sci 43:430-445

Paffenhöfer GA, Lewis KD (1989) Feeding behavior of nauplii of the genus Eucalanus (Copepoda, Calanoida). Mar Ecol Prog Ser 57:129-136

Paffenhöfer GA, Stearns DE (1988) Why is Acartia tonsa (Copepoda: Calanoida) restricted to nearshore environments? Mar Ecol Prog Ser 42:33-38

Paffenhöfer GA, Strickler JR, Lewis KD, Richman S (1996) Motion behavior of nauplii and early copepodite stages of marine copepods. J Plankton Res 18:1699-1715

Piontkovskii SA, Petipa TS (1976) Quantitative description of the behaviour of copepod Acartia clausi during feeding on algae. Sov J Mar Biol 2:40-46

Price JH, Paffenhöfer GA (1986) Effects of concentration on the feeding of a marine copepod in algal monocultures and mixtures. J Plankton Res 8:119-128

Reeve MR, Walter MA (1977) Observations on the existence of lower threshold and upper critical food concentrations for the copepod Acartia tonsa Dana. J Exp Mar Biol Ecol 29:211-221 
Rosenberg GC (1980) Filmed observation of filter feeding in the marine planktonic copepod Acartia clausii. Limnol Oceanogr 25:738-742

Saiz E (1994) Observations of the free-swimming behavior of Acartia tonsa: effect of food concentration and turbulent water motion. Limnol Oceanogr 39:1566-1578

Saiz E, Alcaraz M (1992) Free-swimming behaviour of Acartia clausi (Copepoda: Calanoida) under turbulent water movement. Mar Ecol Prog Ser 80:229-236

Sokal RR, Rohlf FJ (1995) Biometry. WH Freeman, San Francisco, CA

Stoecker DK, Egloff DA (1987) Predation by Acartia tonsa on planktonic ciliates and rotifers. J Exp Mar Biol Ecol 110: 53-68

Strathmann RR (1967) Estimating the organic carbon content of phytoplankton from cell volume or plasma volume. Limnol Oceanogr 12:411-418

Strickler JR (1982) Calanoid copepods, feeding currents, and the role of gravity. Science 218:158-160

Svensen C, Kiørboe T (2000) Remote prey detection in Oithona similis: hydrodynamical versus chemical cues. J Plankton Res 22:1155-1166

Swadling KM, Marcus NH (1994) Selectivity in the natural diets of Acartia tonsa Dana (Copepoda: Calanoida): comparison of juveniles and adults. J Exp Mar Biol Ecol 181:91-103

Tiselius P (1992) Behavior of Acartia tonsa in patchy food environments. Limnol Oceanogr 37:1640-1651

Tiselius P, Jonsson PR (1990) Foraging behaviour of six calanoid copepods: observations and hydrodynamic analysis. Mar Ecol Prog Ser 66:23-33

Editorial responsibility: Thomas Kiørboe (Contributing

Editor), Charlottenlund, Denmark
Tiselius P, Jonsson PR, Kaartvedt S, Olsen EM, Jørstad T (1997) Effects of copepod foraging behavior on predation risk: an experimental study of the predatory copepod Pareuchaeta norvegica feeding on Acartia clausi and A. tonsa (Copepoda). Limnol Oceanogr 42:164-170

Titelman J (2001) Swimming and escape behaviour of copepod nauplii: implications for predator-prey interactions among copepods. Mar Ecol Prog Ser 213:203-213

Titelman J, Fiksen $\varnothing$ (2004) Ontogenetic vertical distribution patterns in small copepods: field observations and model predictions. Mar Ecol Prog Ser 284:49-63

Titelman J, Kiørboe T (2003a) Motility of copepod nauplii and implications for food encounter. Mar Ecol Prog Ser 247: 123-135

Titelman J, Kiørboe T (2003b) Predator avoidance by nauplii. Mar Ecol Prog Ser 247:137-149

Ueda H (1987) Small-scale ontogenetic and diel vertical distributions of neritic copepods in Maizuru Bay, Japan. Mar Ecol Prog Ser 35:65-73

Van Duren LA, Videler JJ (1995) Swimming behaviour of development stages of the calanoid copepod Temora longicornis at different food conditions. Mar Ecol Prog Ser 126:153-161

Wiadnyana NN, Rassoulzadegan FR (1989) Selective feeding of Acartia clausi and Centropages typicus on microzooplankton. Mar Ecol Prog Ser 53:37-45

Wlodarczyk E, Durbin AG, Durbin EG (1992) Effect of temperature on lower feeding thresholds, gut evacuation rate, and diel feeding behavior in the copepod Acartia hudsonica. Mar Ecol Prog Ser 85:93-106

Submitted: January 17, 2005; Accepted: June 17, 2005

Proofs received from author(s): November 3, 2005 